\title{
PENGARUH INFLASI TERHADAP PEMBIAYAAN USAHA MIKRO KECIL MENENGAH (UMKM) TAHUN 2015-2016 \\ DI BPRS AL-MASOEM
}

\author{
Wulan Laelasari \\ Program Studi Akuntansi \\ STIE-STAN IM, Jl. Jakarta No.79 Bandung
}

\begin{abstract}
ABSTRAK
Tujuan penelitian ini adalah untuk mengetahui dan menganalisis pengaruh inflasi terhadap pembiayaan UMKM di BPRS Al-Masoem. Metode pengumpulan data dilakukan dengan menganalisis laporan terkait dengan inflasi serta pembiayaan UMKM periode 2015 sampai 2016. Model analisis data yang digunakan adalah analisis regresi sederhana. Pengujian hipotesis secara parsial dilakukan dengan menggunakan sofware SPSS 17.Hasil penelitian menunjukan bahwa, inflasi memiliki pengaruh negative tidak signifikan terhadap pembiayaan UMKM. Dengan diperoleh pengaruh koefisien variable inflasi terhadap pembiayaan UMKM sebesar $20 \%$.
\end{abstract}

Kata Kunci: Inflasi, Pembiayaan UMKM.

\section{PENDAHULUAN}

Di era globalisasi, perkembangan ekonomi di Indonesia Saat ini sangat baik, perkembangan tersebut tidak lepas dari peran perbankan yang sebagai suatu badan usaha yang memberikan modal pinjaman dana dalam bentuk simpanan dan menyalurkan kepada masyarakat yang membutuhkan pinjaman tersebut. Di dalam Undang-Undang No. 21 Tahun 2008 di sebutkan bahwa bank adalah badan usaha yang menghimpun dana dari masyarakat dalam bentuk simpanan dan menyalukan kepada masyarakat dalam bentuk kredit dan atau bentuk-bentuk lainnya dalam rangka meningkatkan taraf hidup masyarakat.

Perbankan syariah dari tahun ke tahun mengalami peningkatan yang signifikan, baik dari sisi pendanaan maupun pembiayaan. Kondisi perekonomian selalu menarik perhatian perbankan dalam menyalurkan pembiayaan adalah inflasi. Karena ketika terjadi inflasi yang tinggi maka nilai riil uang akan turun keadaan tersebut mengakibatkan masyarakat lebih suka menggunakan uangnya untuk spekulasi antara lain dengan membeli harta tetap seperti tanah dan bangunan. Hal ini akan merugikan perbankan karna nasabah berpotensi melakukan penarikan uang dari perbankan

Fungsi bank sebagai lembaga intermediasi ini membuat bank memiliki posisi yang strategis dalam perekonomian. Aktifitas bank yaitu menghimpun dana dan 
menyalurkan dana kepada masyarakat yang membutuhkan akan meningkatkan arus dana untuk investasi,modal kerja maupun konsumsi. Dengan demikian, akan dapat meningkatkan perekonomian nasional. Landasan sistem ekonomi negara diatur dalam Pasal 33 dan Pasal 34 Undang-Undang Dasar Negara 1945, mengatur tanggungjawab yang dibebankan kepada negara dalam upaya meningkatkan kesejahteraan rakyat. Selain ditujukan kepada negara, tanggungjawab juga dibebankan kepada golongan yang mampu berusaha, dan karena itu dalam pasal 33 Undang-Undang Dasar Negara 1945 memuat semangat kebersamaan (kekeluargaan), sumber-sumber kemakmuran dan kesejahteraan sosial, pelaku usaha, bangunan dan wadah/bentuk usaha, cara penggunaan/proses berusaha, serta tujuan akhir kegiatan usaha yaitu untuk mencapai kemakmuran dan kesejahteraan bersama.

Dalam proses pembangunan ekonomi nasional, sampai saat ini struktur ekonomi Indonesia disangga oleh para pelaku usaha yang tergabung dalam kelompok usaha mikro, usaha kecil, usaha menengah, dan kelompok usaha besar. Sumbangan dari kelompok ini sangat berarti dalam perekonomian nasional. Usaha mikro, kecil, dan menengah (UMKM) merupakan salah satu pilar utama perekonomian nasional yang berwawasan kemandirian memiliki potensi besar untuk meningkatkan kesejahteraan masyarakat, tanpa mengabaikan peran usaha besar, koperasi, maupun BUMN.

Pembiayaan Usaha Mikro Kecil dan Menengah (UMKM) dimana kegiatan ini berkembang pesat dalam perekonomian nasional. UMKM menjadi wadah bagi penciptaan lapangan pekerjaan yang sangat efisien dan bersifat padat karya, kegiatan ini tidak membutuhkan persyaratan tertentu seperti tingkat pendidikan dan keterampilan. Keberadaan UMKM bukan hanya dianggap penampungan sementara bagi para pekerja yang belum masuk ke sektor formal, tetapi juga sebagai motor pertumbuhan aktivitas ekonomi. Hal ini dikarenakan jumlah penyerapan tenaga kerjanya yang demikian besar. Mengingat pengalaman yang telah dihadapi oleh Indoneisia selama krisis ekonomi, kiranya tidak berlebihan apabila pengembangan sektor swasta difokuskan pada UMKM.

Faktor tersebut juga menyebabkan rendahnya tingkat kepercayaan lembaga perbankan dan lembaga keuangan lainnya untuk memberikan bantuan permodalan dalam bentuk kredit terhadap UMKM. Selain itu, 
ketidakmampuan UMKM untuk menyediakan jaminan (agunan) telah menyulitkan UMKM untuk mengakses kredit dari perbankan.

Tingginya tingkat inflasi menunjukkan bahwa risiko untuk melakukan investasi cukup besar sebab inflasi yang tinggi akan mengurangi tingkat pengembalian (rate of return) dari investor. Pada kondisi inflasi yang tinggi maka harga barang-barang atau bahan baku memiliki kecenderungan untuk meningkat. Peningkatan harga barangbarang dan bahan baku akan membuat biaya produksi menjadi tinggi sehingga akan berpengaruh pada penurunan jumlah permintaan yang berakibat pada penurunan penjualan sehingga akan mengurangi pendapatan perusahaan. Selanjutnya akan berdampak buruk pada kinerja perusahaan yang tercermin pula oleh turunnnya return saham (Nurdin, 1999).

Peran pemerintah dalam memajukan perbankan syariah belum begitu bagus, perbankan Indonesia masih didominasi oleh perbankan konvensional. Sejumlah bank masih menghadapi kendala pemenuhan rasio kredit UMKM, baik secara internal maupun eksternal. Dari sisi internal, kurangnya kapabilitas bank dalam penyaluran kredit UMKM menjadi kendala utama.

Dari penyaluran dana UMKM masih di dominasi oleh perbankan konvensional dengan persentase bunga rendah sebesar $12 \%$ pada tahun 2015 dan $9 \%$ pada tahun 2016. Data konsolidasi BI menjelaskan peningkatan UMKM yang signifikan ini karena dipengaruhi oleh suku bunga yang rendah. Meningkatnya penyaluran Kredit Usaha Rakyat (KUR) membuat bank nonpenyalur KUR semakin kesulitan dalam mendapatkan debitur baru yang potensial. Margin perbankan syari'ah jauh dlebih mahal dibandingkan suku bunga KUR yang rendah,oleh karena itu Perbankan syari'ah Indonesia masih belum bisa melaju pesat seperti perbankan konvensional.

\section{REVIEW LITERATUR \& PENGEMBANGAN HIPOTESIS}

Pembiayaan merupakan aktivitas bank syariah dalam menyalurkan kepada pihak nasabah yang membutuhkan dana. Berikut adalah produk-produk pembiayaan bank syariah: Pembiayaan dengan pola bagi hasil Pada pembiayaan umum yang ada pada UMKM ada tiga pola bagi hasil yang digunakan yaitu:

a) Al-Mudharabah Al-Mudharabah adalah akad kerja sama usaha anatara dua pihak dimana pihak pertama (shahibul maal) menyediakan seluruh modal, sedangkan 
pihak lainnya menjadi pengelola. Keuntungan usaha secara mudharabah dibagi menurut kesepakatan yang dituangkan dalam kontrak, sedangkan apabila rugi, ditanggung oleh pemilik modal selama kerugian tersebut bukan akibat kelalaian di pengelola. Seandainya kerugian diakibatkan karena kecurangan atau kelalaian si pengelola, maka pengelola harus bertanggung jawab atas kerugian tersebut.

b) Al-Musyarakah Al-Musyarakah adalah akad kerja sama antara dua pihak atau lebih untuk suatu usaha tertentu dimana masing-masing pihak memberikan kontribusi dana dengankesepakatan bahwa keungan dan resiko akan ditanggung bersama sesuai dengan kesepakatan. Al-Musyarakah ada dua jenis yaitu musyarakah pemilikan dan musyarakah akad (kontrak). Musyarakah pemilikan tercipta karena warisan, wasiat, atau kondisi lainnya yang mengakibatkan pemilikan satu aset oleh dua orang atau lebih, sedangkan musyarakah akadtercipta dengan carakespakatan dimana dua orang atau lebih setuju bahwa tiap orang dari mereka memberikan modal musyarakah.

Teori tentang Inflasi menurut (samoelson 2001) sebagai suatu keadaan dimana terjadi kenaikan tingkat harga umum, baik barang-barang, jasa-jasa maupun faktorfaktor produksi. Dari definisi tersebut mengindikasikan keadaan melemahnya daya beli yang diikuti dengan semakin merosotnya nilai riil (intrinsik) mata uang suatu negara.. Inflasi dianggap sebagai fenomena moneter, karena terjadinya penurunan nilai unit penghitungan moneter terhadap suatu komoditas. Inflasi (inflation) adalah gejala yang menunjukan kenaikan tingkat harga umum yang berlangsung terus menerus. Kenaikan harga tersebut dimaksud bukan terjadi sesaat. Dari pengertian tersebut, maka apabila terjadi kenaikan harga hanya bersifat sementara, tidak dapat dikatakan inflasi

\section{Hipotesis Penelitian}

Adapun perumusan hipotesa penelitian ini adalah sebagai berikut :

H1 : Terdapat pengaruh signifikan antara Inflasi terhadap pembiayaan UMKM secara parsial.

H0 : Tidak terdapat pengaruh signifikan antara Inflasi terhadap pembiayaan UMKM secara parsial. 


\section{METODE DAN PROSEDUR PENELITIAN}

Pendekatan penelitian yang digunakan dalam penelitian ini adalah pendekatan penelitian kuantitatif. Penelitian kuantitatif adalah penelitian yang mengacu pada angkaangka. Menurut tingkat eksplanasinya, penelitian ini tergolong penelitian asosiatif. Penelitian asosiatif adalah suatu permasalahan yang berhubungan antara dua variabel atau lebih. Hubungan variabel dalam penelitian adalah hubungan kausal, yaitu hubungan yang bersifat sebab akibat. Ada variabel independent (variabel bebas) dan variabel dependent (variabel terikat). Variabel independent dalam penelitian ini inflasi dan variabel dependent adalah Pembiayaan UMKM di BPRS periode 2015-2016.

\section{TEMUAN - TEMUAN}

\section{a. Uji Normalitas}

TABEL 1. Histogram Normality Test

One-Sample Kolmogorow-Smirnow Test

\begin{tabular}{|ll|r|}
\hline & & $\begin{array}{c}\text { Unstandardiz } \\
\text { ed Residual }\end{array}$ \\
\hline Normal Parameters & \\
& & 24 \\
Most Extreme Differences & Mean & .0000000 \\
& Std. Deviation & $2.76890974 \mathrm{E}$ \\
& Absolute & .144 \\
& Positive & .089 \\
Kolmogorov-Smirnov $Z$ & Negative & -.144 \\
Asymp. Sig. (2-tailed) & & .704 \\
\multicolumn{2}{|c|}{ a. Test distribution is Normal. } & .704 \\
\hline
\end{tabular}

Dari tabel 1 di atas, Nilai Prob. JB hitung sebesar 0.452>0,05 sehingga dapat disimpulkan bahwa residual terdistribusi normal yang artinya asumsi klasik tentang kenormalan telah dipenuhi. Oleh karena itu, model regresi berganda yang menggunakan data tersebut layak dipakai untuk memprediksi seberapa besar pengaruh dari variabel bebas terhadap variabel terikat.

\section{b. Uji Multikolinieritas}

Uji multikolinieritas digunakan untuk mengetahui apakah dalam model regresi berganda tersebut variabel bebasnya saling berkorelasi atau tidak. Untuk mendapatkan model regresi berganda yang baik, maka variabel bebasnya tidak boleh saling berkorelasi. Cara yang digunakan untuk mendeteksi multikolinieritas dalam penelitian ini adalah dengan menggunakan VIF (Variance Inflation Factors) dengan menggunakan sofware SPSS. 


\section{TABEL 2. Hasil Uji Multikolinieritas VIF (Variance Inflation Factors)}

\begin{tabular}{|c|c|c|c|c|c|c|c|c|}
\hline \multicolumn{9}{|c|}{ Coefficients $^{a}$} \\
\hline \multirow[b]{2}{*}{ Model } & & \multicolumn{2}{|c|}{ Unstandardized Coefficients } & \multirow{2}{*}{$\begin{array}{c}\begin{array}{c}\text { Standardized } \\
\text { Coefficients }\end{array} \\
\text { Beta } \\
\end{array}$} & \multirow[b]{2}{*}{$t$} & \multirow[b]{2}{*}{ Sig. } & \multicolumn{2}{|c|}{ Collinearity Statistics } \\
\hline & & $\mathrm{B}$ & Std. Error & & & & Tolerance & VIF \\
\hline 1 & (Constant) & 45303.342 & 18099.022 & & 2.503 & .020 & & \\
\hline & inflasi & -3351.767 & 3460.309 & -.202 & -.969 & .343 & 1.000 & 1.000 \\
\hline
\end{tabular}

Dari tabel 2 di atas. hasil uji multikolinieritas, dapat dilihat pada tabel kolom Centered VIF. Nilai untuk variabel independen di atas memiliki nilai VIF kurang dari 10. maka dapat dikatakan tidak terjadi multikolinieritas pada kedua variabel bebas tersebut. Berdasarkan syarat asumsi klasik regresi linier, maka model regresi linier yang baik adalah yang terbebas dari adanya multikolinieritas. Dengan demikian, model di atas telah terbebas dari adanya multikolinieritas.

\section{c. Uji Heteroskedastisitas}

Uji Heteroskedastisitas dilakukan bertujuan untuk menguji apakah dalam model regresi terjadi ketidaksamaan variance dari residual satu pengamatan ke pengamatan yang lain. Jika variance dari residual satu pengamatan ke pengamatan yang lain berbeda maka disebut heteroskedastisitas. Model regresi yang baik adalah yang memiliki kesamaan variance atau homoskedastisitas.

TABEL 3

Coefficients $^{a}$

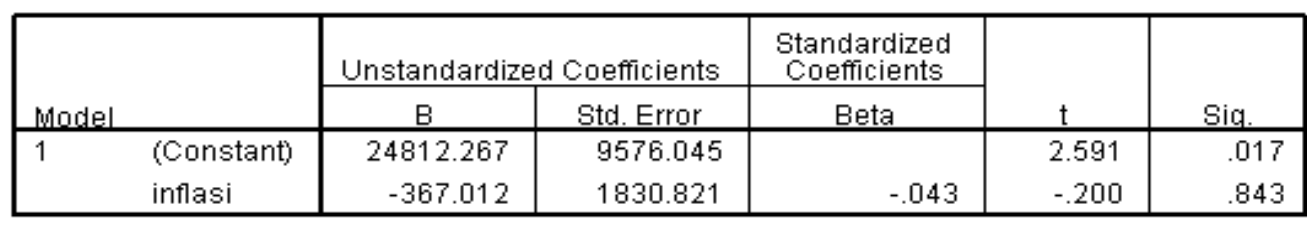

a. Dependent Variable: RES_3

Dari semua uji di atas, nilai Prob. dari Signifikansi hitung lebih besar dari tingkat alpha 0,05 maka dapat disimpulkan tidak terjadi heteroskedastisitas.

\section{d. Autokorelasi}

Uji autokorelasi dilakukan untuk menguji asumsi bahwa data yang digunakan bersifat bebas. Data yang digunakan dalam analisis regresi berganda pada periode tertentu tidak boleh dipengaruhi atau mempengaruhi data periode sebelumnya maupun sesudahnya. apabila terjadi autokorelasi, maka model regresi yang dihasilkan melalui sampel tidak dapat menggambarkan varian populasinya. pengujian dengan 
menggunakan uji t dan uji $\mathrm{F}$ tidak akan efektif lagi.

Berdasarkan olah data dengan menggunakan SPSS 17 diperoleh hasil sebagai berikut:

TABEL 4.

\begin{tabular}{|c|c|c|c|c|c|}
\hline \multicolumn{7}{|c|}{ Model Summary } \\
\hline Model & $\mathrm{R}$ & R Square & $\begin{array}{c}\text { Adjusted R } \\
\text { Square }\end{array}$ & $\begin{array}{c}\text { Std. Error of } \\
\text { the Estimate }\end{array}$ & $\begin{array}{c}\text { Durbin- } \\
\text { Watson }\end{array}$ \\
\hline 1 & $.202^{a}$ & .041 & -.003 & 28311.402 & .559 \\
\hline
\end{tabular}

$\mathrm{k}=2, \mathrm{n}=25$, menurut tabel durbin watson diperoleh $\mathrm{dL}=1.1878 \mathrm{du}=1.5464$

Nilai DW terletak diantara dU dan 4-dU jadi terdapat autokorelasi.

\section{Hasil Uji Hipotesis}

\section{a. Regresi Linier}

\section{Uji t}

\section{TABEL 5.}

Coefficients ${ }^{-}$

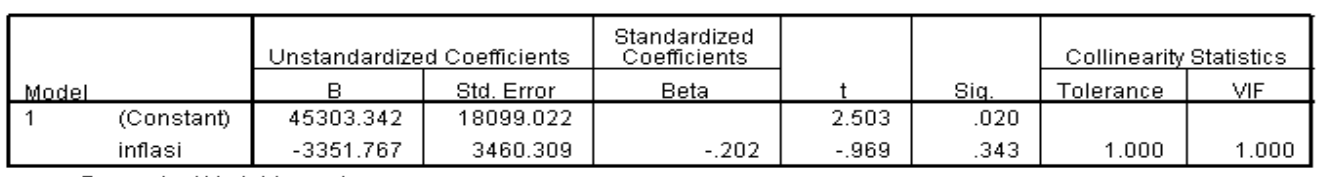

a. Dependent Variable: umkm

Hasil uji t dapat dilihat pada tabel 4.6 di atas. Apabila nilai prob. $\mathrm{t}$ hitung (ditunjukkan pada Prob.) sebesar -0.969 dan tingkat signifikansi sebesar 0.343 lebih besar dari tingkat kesalahan (alpha) 0,05 maka dapat dikatakan bahwa variabel inflasi berpengaruh negatif tidak signifikan terhadap Pembiayaan Usaha Mikro Kecil dan Menengah(UMKM.

\section{Uji $R^{2}$}

TABEL 6.

\begin{tabular}{|c|c|c|c|c|c|}
\hline \multicolumn{6}{|c|}{ Model Summary } \\
\hline Model & $\mathrm{R}$ & R Square & $\begin{array}{l}\text { Adjusted R } \\
\text { Square }\end{array}$ & $\begin{array}{l}\text { Std. Error of } \\
\text { the Estimate }\end{array}$ & $\begin{array}{l}\text { Durbin- } \\
\text { Watson }\end{array}$ \\
\hline 1 & $.202^{a}$ & .041 & -.003 & 28311.402 & .559 \\
\hline
\end{tabular}


Nilai R pada tabel 4.7 di atas besarnya 0.202 menunjukkan bahwa proporsi pengaruh Inflasi terhadap Pertumbuhan UMKM sebesar 20\%. Artinya Inflasi memiliki proporsi pengaruh terhadap Pembiayaan Usaha Mikro Kecil dan Menengah (UMKM) sebesar $20 \%$. sedangkan sisanya $80 \%$ dipengaruhi oleh variabel lain yang tidak diteliti.

\section{PEMBAHASAN}

Setelah melakukan analisis terhadap hipotesis yang diuji dalam penelitian ini, maka dapat ditarik beberapa kesimpulan sebagai berikut :

Dari hasil pengolahan data bahwa Inflasi berpengaruh negative tidak signifikan terhadap pembiayaan UMKM. Dengan pengaruh koefisien variable inflasi terhadap Pembiayaan UMKM sebesar 20\%. Hal ini sekaligus menolak teori Teori tentang Inflasi sebagai suatu keadaan dimana terjadi kenaikan tingkat harga umum, baik barangbarang, jasa-jasa maupun faktor-faktor produksi. Dari definisi tersebut mengindikasikan keadaan melemahnya daya beli yang diikuti dengan semakin merosotnya nilai riil (intrinsik) mata uang suatu negara. Ternyata tidak ada pengaruh yang signifikan inflasi terhadap pertumbuhan UMKM.

Hal ini sekaligus menolak teori Teori tentang Inflasi sebagai suatu keadaan dimana terjadi kenaikan tingkat harga umum, baik barang-barang, jasa-jasa maupun faktor-faktor produksi. Dari definisi tersebut mengindikasikan keadaan melemahnya daya beli yang diikuti dengan semakin merosotnya nilai riil (intrinsik) mata uang suatu negara. Ternyata tidak ada pengaruh yang signifikan inflasi terhadap pembiayaan UMKM. Walaupun terjadi tingkat inflasi yang berubah- ubah selama periode pengamatan tidak akan mempengaruhi jumlah pembiayaan, dan pembiayaan malah semakin meningkat, artinya walaupun terjadi inflasi dan masyarakat sangat membutuhkan dana untuk membuka usaha, maka masyarakat tetep membutuhkan pembiayaa.

\section{DAFTAR PUSTAKA}

Adisasmita, H.R. Dasar-dasar Ekonomi Wilayah. Jakarta, Graha Ilmu, 2008.

Alisjahbana, Armida. Desentralisasi Fiskal dan Kebijakan Pembangunan Ekonomi Daerah. Makassar, Kongres ISEI XIV, 2000.

Arsyad,Lincolin. Pengantar Perencanaan dan Pembangunan Ekonomi Daerah.Yogyakarta, BPFE, 1999. 
Boediono, 2007. Teori Pertumbuhan Ekonomi. Yogyakarta, BPFE

Burhan, M. Bungin. Metodelogi Penelitian Kuantitatif. Jakarta: Perdana Media,2005.

Darmawi, Herman.Manajemen Perbankan. Jakarta: PT Bumi Aksara,2012.

Eko, Agus Sujianto.Aplikasi Statistik dengan SPSS 16,0. Jakarta: PT. Prestasi Pusta Karya, 2009.

Gujarati, D.Alih bahasa Sumarno Zain. Ekometri Dasar. Jakarta: Erlangga, 2003.

Irianto, Agus. Statistik Konsep Dasar dan Aplikasinya. Jakarta : Prenada Media Group, 2007.

Islahuzzaman, Istilah-Istilah Akuntansi dan Auditing. Jakarta:Bumi Aksara, 2012.

Iswardono.1999.Uang Dan Bank edisi 4.Yogyakarta:BPFE-Yogyakarta Jhingan, M.L. 2000. Ekonomi Pembangunan dan Perencanaan. Jakarta, PT. Raja Grafindo Persada

Karim, Adiwarman. Bank Islam. Analisis fiqih dan keuangan. Jakarta: Rajawali Pers, 2009.

Karim, Adiwarman A. Bank Islam: Analisis Fiqh dan Keuangan. Cetakan Ke-3. Jakarta: PT Raja Grafindo Persada, 2006.

Kasmir, Bank dan Jasa Keuangan lainnya, Jakarta; PT Raja Grafindo Persada, 2008.

Mangkunegara, A.P. Perilaku Konsumen. Edisi Revisi. Cetakan Keempat. Bandung: PT Refika Aditama, 2009.

Muslimin Kara. Bank Syariah di Indonesia, Yogyakarta, 2005.

Muhammad.Manajemen Dana Bank Syariah. Yogyakarta: Ekonisia, 2004.

Muhammad Syafi'i Antonio, Bank Syariah Dari Teori ke Praktik, Jakarta: Gema Insani Press, 2001.

Muhamad. Sistem dan Prosedur Operasional Bank Syariah. Yogyakarta: UII Press, 2001 .

Munir. 2002. Perencanaan Pembangunan Daerah Dalam Perspektif Otonomi. NTB,

Samuelson, Paul A dan William D. Nordhaus. Makro Ekonomi, Edisi keempatbelas.

Jakarta, 2001.

Sinungan Muchdarsyah, Manajemen Dana Bank. Jakarta: Bumi Aksara, 2000.

Sudarsono Heri. Bank dan Lembaga Keuangan Syari'ah: Deskripsi dan ilustrasi, Yogyakarta, 2003.

Sugiyono, MetodologiPenelitian Bisnis, Bandung: Alfabeta, 2009.

Suryana, Kewirausahaan, Jakarta : Salemba Empta, 2003. 
Sutisna, Perilaku Konsumen dan Komunikasi Pemasaran. Bandung: PT Remaja Rosdakarya, 2002.

Syafei, Rachmat. Fiqih Muamalah. Bandung: Pustaka Setia, 2000. 